\title{
Impact of biopersistent fibrous dusts on glycolysis, glutaminolysis and serine metabolism in A549 cells
}

\author{
SYBILLE WACHE $^{1}$, SIMONE HELMIG $^{2}$, DIRK WALTER ${ }^{2}$, JOACHIM SCHNEIDER $^{2}$ and SYBILLE MAZUREK ${ }^{1}$ \\ ${ }^{1}$ Institute of Veterinary Physiology and Biochemistry; ${ }^{2}$ Institute and Outpatient Clinic for Occupational \\ and Social Medicine, Justus Liebig University Giessen, D-35392 Giessen, Germany
}

Received March 29, 2017; Accepted August 15, 2017

DOI: $10.3892 / \mathrm{mmr} .2017 .7729$

\begin{abstract}
The conversion rates of different metabolic pathways summarized as a metabolic signature mirror the physiological functions and the general physiological status of a cell. The present study compared the impact of crocidolite and chrysotile asbestos, glass fibers and multi-walled carbon nanotubes (MWCN) of two different lengths (1-2 $\mu \mathrm{m}$ and $5-15 \mu \mathrm{m}$ ) on the conversion rates in glycolysis, glutaminolysis and serine metabolism of A549 cells. The concentration tested was $1 \mu \mathrm{g} / \mathrm{cm}^{2}$ for all fibers. A concentration of $5 \mu \mathrm{g} / \mathrm{cm}^{2}$ was additionally used for chrysotile and crocidolite, and $25 \mu \mathrm{g} / \mathrm{cm}^{2}$ for glass fibers and MWCN. With respect to the inhibitory effect on cell proliferation and the extent of metabolic alterations, the present study revealed the following ranking among the fibers tested: Chrysotile $>$ crocidolite $>$ glass fibers $>$ MWCN 5-15 $\mu \mathrm{m}>\mathrm{MWCN} 1-2 \mu \mathrm{m}$. For the asbestos and glass fibers this ranking correlated best with the number of fibers. It appeared that the results observed for MWCN did not match this correlation. However, electron microscopy revealed an agglomeration of MWCN. The agglomeration decreased the toxicologically relevant number of fibers by forming larger particle-like shapes and explained the smaller effects of MWCN 5-15 $\mu \mathrm{m}$ and 1-2 $\mu \mathrm{m}$ on cell proliferation and metabolism.
\end{abstract}

\section{Introduction}

Biopersistent fibrous dusts are present in natural mineral stones and may arise during certain industrial production processes. Well-known examples of natural minerals are asbestos fibers. The two most important industrial asbestos minerals associated with occupational diseases are crocidolite and chrysotile. Industrially-synthesized inorganic fibers which are substitutes for asbestos are termed man-made mineral fibers (1), primary

Correspondence to: Dr Sybille Mazurek, Institute of Veterinary Physiology and Biochemistry, Justus Liebig University Giessen, 100 Frankfurter Street, D-35392 Giessen, Germany

E-mail: sybille.mazurek@vetmed.uni-giessen.de

Key words: fibrous dusts, glycolysis, glutaminolysis, serinolysis, metabolic signature examples of which are glass fibers [man-made vitreous fibers (MMVF)], ceramic fibers (including refractory ceramic fibers) and, more recently, carbon nanotubes. Epidemiological studies have confirmed an increased risk of lung carcinoma and mesothelioma following exposure to asbestos $(2,3)$. Due to their geological formations, asbestos fibers vary in chemical composition, length and diameter. Inhalable asbestos fibers of critical dimensions were defined as World Health Organization (WHO; Geneva, Switzerland) fibers: Length $\geq 5 \mu \mathrm{m}$, diameter $<3 \mu \mathrm{m}$, length:diameter ratio >3:1 (4). However, this convention is not a robust criterion by which to categorize fibers as toxic. Previous animal studies revealed that nano-sized fibers, including silver nano wires $(5,6)$, multiwall carbon nanotubes and rigid carbon nanotubes (7) may induce asbestos-like granulomatous inflammation and fibrogenic effects in the lung tissues and pleura $(8,9)$. In order to determine the toxicity of fibers, the chemical composition, as the ultimate cause of biopersistence, in addition to the surface reactivity of the fibers are as important as fiber length and diameter (10).

Chemicals, including fibrous dusts, may act in a number of ways on human and animal cells. They may induce genetic mutations, influence the transcription and translation rate of genes or affect protein functions, such as enzyme activities, via intervention in post-translational regulatory protein kinase cascades. A number of previous studies have assessed the impact of different dusts on the expression of genes using genomic, transcriptomic and proteomic analytical techniques (11-14). The impact of the chemicals on different genes and their expression products may potentiate or annul each other. The end product of the complex regulatory mechanisms and external interventions which take place at the level of DNA, mRNA and protein are the conversion rates of the corresponding pathways. In its entirety, the conversion rates of the different metabolic pathways of cells, which are summarized as the metabolic signature, mirror the physiological functions and the general physiological status of the cells. The present study investigated the effect of different fibrous dusts on three important metabolic pathways (glycolysis, glutaminolysis and serine metabolism) of A549 human lung adenocarcinoma cells in cell culture.

Following inhalation and deposition of dust particles in the lung, the primary target cells affected are alveolar macrophages and alveolar epithelial cells. The A549 cells used in the present study are morphologically assigned to type II alveolar epithelial 
cells (15). Type II alveolar epithelial cells are characterized by their surfactant synthesis in addition to the proliferation and differentiation of stem cells following damage to type I epithelial cells (16). Therefore, alveolar epithelial type II cells are of particular importance when inflammatory damage to the lung occurs. A549 cells contain a number of metabolic features and transport properties characteristic of type II pneumocytes, including cytochrome P450 1A1 and 2B6, tannic acid-positive lamellar bodies, concentration-dependent internalization of cationized ferritin, and uptake of transferrin (17). A549 is a permanent cell line developed in 1972 by Giard et al (18) from a human lung carcinoma. An advantage of A549 cells is their high growth rate and cellular homogeneity. Due to their ability to perform unlimited cell division A549 cells are suited to long-term experimentation. In addition, A549 are capable of internalizing particles (19). According to Castell et al (20), A549 cells are the most suitable cell line for the investigation of chemically-induced and lung-specific toxicity. Foster et al (17) suggested the cell line as a standard model for the investigation of type II lung epithelial cells and drug metabolism. A549 cells have been used to investigate the impact of inhalative chemicals in a high number of publications (12,20-23). In comparison to BEAS-2B cells, a bronchoepithelial cell line genetically modified and immortalized by the adenovirus 12-SV40 virus hybrid (Ad12SV40), A549 cells are more stable in cell culture and have been extensively characterized regarding cell viability, transcription factors and signaling molecules $(24,25)$. The A549 cells used in the present study are classified as a p53 wild type lung cell line in the documentation of one of the provider (26).

In proliferating cells, including normal proliferating cells, embryonic cells, adult stem cells and immortalized cells, energy is regenerated in two pathways: Glycolysis and glutaminolysis (Fig. 1) (27-29). In glycolysis, net ATP production occurs in the pyruvate kinase reaction. The degradation of glutamine via glutaminolysis recruits reaction steps of the citric acid cycle and depends on oxygen. In addition, intermediates of glycolysis, glutaminolysis and serine metabolism serve as substrates for the synthesis of important cellular building blocks, such as nucleic acids, phospholipids, amino acids and C1-building blocks for folic acids (Fig. 1). Therefore, cell division of proliferating cells only proceeds when the cellular metabolism is capable of providing a high enough concentration of intermediates to ensure energy regeneration, and the synthesis of cellular building blocks in sufficient amounts $(29,30)$. In order to obtain an impression of whether or not chemicals have an impact on the conversion rates of glycolysis, glutaminolysis and serine metabolism, a rapid and effective method is to measure the conversion rates of their corresponding substrates (glucose, glutamine and serine) and metabolic products (lactate and glutamate) in the culture supernatants of the cells in cell culture.

The present study compared the impact of the following fibrous dusts on the glucose, glutamine and serine conversion rates of A549 cells: i) Crocidolite and chrysotile asbestos, as biopersistent fibrous dusts with documented carcinogenic characteristics; ii) glass fibers, as an example of low-biopersistence MMVF (2); and iii) biopersistent multi-walled-carbon-nanotubes (MWCN) with two different lengths, at 1-2 $\mu \mathrm{m}$ and 5-15 $\mu \mathrm{m}$. In contrast with crocidolite, chrysotile and glass fibers, short MWCN do not fulfil the geometric ratios of the WHO fiber criteria. The two types of MWCN, which were produced under the same reaction conditions, are characterized by an identical chemical composition and diameter, although they differ in length. This selection of fibers allowed for the comparison of different biopersistent WHO fibers. Additionally, the effect of length was evaluated in the case of MWCN.

\section{Materials and methods}

Fibrous dusts. Crocidolite asbestos was obtained from the Union Internationale Contre le Cancer (UICC; WHO; South African NB \#4173-111-3). Chrysotile asbestos was obtained from UICC (Rhodesian NB \#4173-11-2). Glass fibers (MMVFs) were removed from commercial glass wool used for insulation. Biopersistent MWCN (1-2 $\mu \mathrm{m}$ MWCN; cat. no. CP-0012-SG and 5-15 $\mu \mathrm{m}$ MWCN; cat. no. CP-0009-SG) were purchased from Ionic Liquids Technologies $\mathrm{GmbH}$ (Heilbronn, Germany).

Techniques used for fibrous dust characterization. Scanning electron microscopy (SEM; Hitachi S-2700; Hitachi, Ltd., Tokyo, Japan) was used to identify particle geometry in addition to the microstructure of the fibers. The element analysis resulted from energy dispersive X-rays (EDX). To optimize the conductivity (electron beam), all fiber samples were sputtered with a fine layer of Au. Transmission electron microscopy analysis combined with electron diffraction (detection of crystallinity) was performed using a transmission electron microscope (H-7100; Hitachi, Ltd.).

Culture conditions and metabolite measurements. A549 cells were obtained from the European Collection of Authenticated Cell Cultures (Salisbury, UK; cat. no. 86012804). The cells were cultured in Gibco ${ }^{\circledR}$ RPMI 1640 (Thermo Fisher Scientific, Inc., Waltham, MA, USA), supplemented with $2 \mathrm{mM}$ L-glutamine, $1 \%$ (v/v) antibiotics (penicillin, $100 \mathrm{U} / \mathrm{ml}$ and streptomycin, $100 \mu \mathrm{g} / \mathrm{ml}$ ) and $10 \%(\mathrm{v} / \mathrm{v})$ fetal calf serum (Thermo Fisher Scientific, Inc.) at $37^{\circ} \mathrm{C}$ in a $5 \% \mathrm{CO}_{2}$ environment. For the flux experiments, 12-well dishes (for $24 \mathrm{~h}$ exposure time) and 24-well dishes (for $48 \mathrm{~h}$ exposure time) were used (both Sarstedt AG \& Co., Nümbrecht, Germany). The experiments were begun with an initial cell number of $9.0 \times 10^{4}$ cells/well in the 12 -well plates and $7.0 \times 10^{4}$ cells/well in the 24 -well plates. Following $24 \mathrm{~h}$ of pre-culture, the culture media of the cells were exchanged for culture media with different fibers. Stock solutions with $5 \mathrm{mg}$ of the respective fibers suspended in $1 \mathrm{ml}$ PBS (cat. no. BIO-37108; Bioline Reagents, Ltd., London, UK) were diluted with fresh culture medium to a concentration of $1 \mu \mathrm{g} / \mathrm{cm}^{2}$, and $25 \mu \mathrm{g} / \mathrm{cm}^{2}$ for glass fibers and MWCN or $5 \mu \mathrm{g} / \mathrm{cm}^{2}$ for the two types of asbestos. Control cells were mock-treated with PBS buffer. Following $24 \mathrm{~h}$ culture for the first culture approach (low concentration), and $48 \mathrm{~h}$ for the second approach (high concentration), the culture supernatants were collected, centrifuged at $460 \mathrm{x} g$ at room temperature for $5 \mathrm{~min}$ in order to remove fibers from the medium and immediately frozen at $-80^{\circ} \mathrm{C}$. The cells in the corresponding wells were trypsinized, diluted 1:2 with trypan blue and counted using a Neubauer chamber. The frozen culture supernatants were heated for $15 \mathrm{~min}$ at $95^{\circ} \mathrm{C}$ and subsequently 


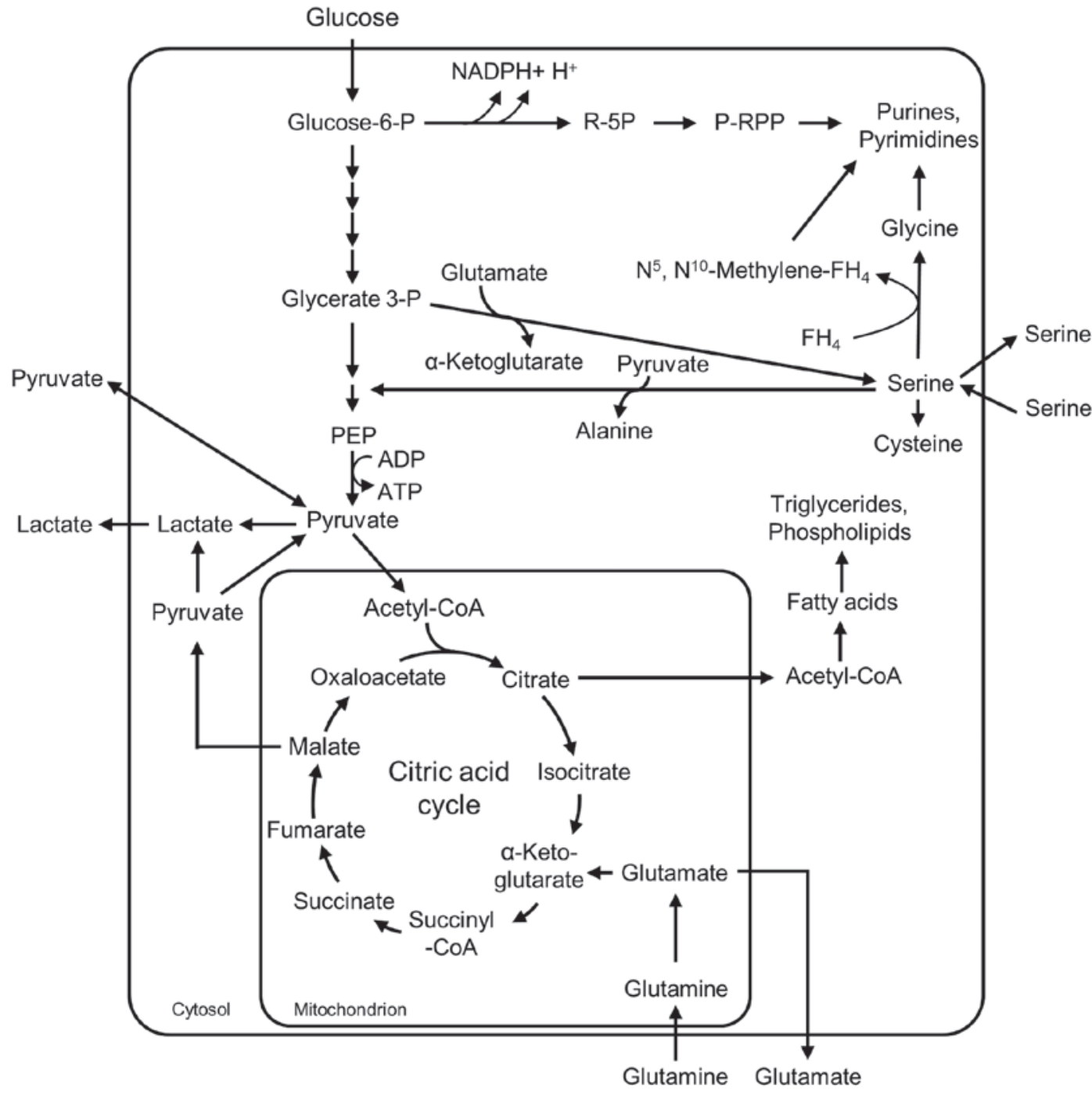

Figure 1. Metabolic overview of glycolysis, glutaminolysis and serine metabolism. R-5P, ribose-5-phosphate; P-RPP, 5-phosporibosyl-1-pyrophosphate; $\mathrm{NADPH}+\mathrm{H}^{+}$, reduced nicotinamide adenine dinucleotide phosphate; $\mathrm{CoA}$, coenzyme $\mathrm{A} ; \mathrm{FH}_{4}$, tetrahydrofolate.

centrifuged at $8,000 \mathrm{x} \mathrm{g}$ at room temperature for $10 \mathrm{~min}$ (31). Glucose, lactate, pyruvate, glutamine, glutamate and serine were determined using a bench top random clinical analyzer, as described by Unterluggauer et al (32). The conversion rates of the metabolites in $\mathrm{nmol} /\left(\mathrm{h} \times 10^{5}\right.$ cells $)$ were calculated as the difference between medium samples from dishes with cells and medium samples incubated in parallel dishes without cells.

Statistical analysis. Results are presented as the mean \pm standard error of the mean for each condition, compared with the mean of the results from control samples. All statistical analyses were performed using the statistical software package SSPS 17.0 (SPSS Inc., Chicago, IL, USA). A comprehensive one-way analysis of variance with repeated measures combined with a Student Newman Keuls post hoc test was performed. $\mathrm{P}<0.05$ was considered to indicate a statistically significant difference.

\section{Results and Discussion}

Characterization of the fibrous dusts by electron microscopy. UICC crocidolite South African, a ferrous rod-like fiber with the chemical formula $\mathrm{Na}_{2}\left(\mathrm{Fe}_{3}{ }^{2+} \mathrm{Fe}_{2}{ }^{3+}\left[(\mathrm{OH})_{2} \mathrm{Si}_{8} \mathrm{O}_{22}\right]\right)$, is composed of $130 \times 10^{6} \mathrm{WHO}$ fibers $/ \mathrm{mg}$ with a length of $>5 \mu \mathrm{m}$, a diameter of $<3 \mu \mathrm{m}$, and a length:diameter ratio $>3: 1$. Crocidolite is a rigid and rod-like fiber with a characteristic iron content (13). UICC chrysotile 'A' Rhodesian (chemical structural formula, $\mathrm{Mg}_{6}\left[(\mathrm{OH})_{8} \mathrm{Si}_{4} \mathrm{O}_{10}\right]$, with an approximately equal $\mathrm{Mg} / \mathrm{Si}$ distribution) is composed of $800 \times 10^{6} \mathrm{WHO}$ fibers/mg. These fibers are of a curly, pliable structure (13). The WHO fraction of the glass fibers is composed of $0.26 \times 10^{6}$ fibers/mg. EDX analysis revealed the following chemical composition: $70.0 \% \mathrm{SiO}_{2} ; 14.3 \% \mathrm{CaO} ; 9.7 \% \quad \mathrm{Na}_{2} \mathrm{O} ; 2.5 \%$ $\mathrm{MgO} ; 2.3 \% \mathrm{~K}_{2} \mathrm{O}$; and $1.2 \% \mathrm{Al}_{2} \mathrm{O}_{3}$. Glass fibers are characteristic of an amorphous material. A diffraction pattern was not detectable by transmission electron microscopy (Helmig et al, unpublished). In contrast with chrysotile, crocidolite and glass fibers, the nano-sized 1-2 $\mu \mathrm{m} \mathrm{MWCN} \mathrm{(CP-0012-SG)} \mathrm{and}$ 5-15 $\mu \mathrm{m}$ MWCN (CP-0009-SG) agglomerate to larger units with diameters of $\sim 5 \mu \mathrm{m}$ in a suspension (Figs. 2 and 3).

Impact of chrysotile, crocidolite, glass fibers, MWCN 5-15 $\mu \mathrm{m}$ and MWCN 1-2 $4 \mathrm{~m}$ on the proliferation rate of A549 cells. The aim of the present study was to investigate the impact 

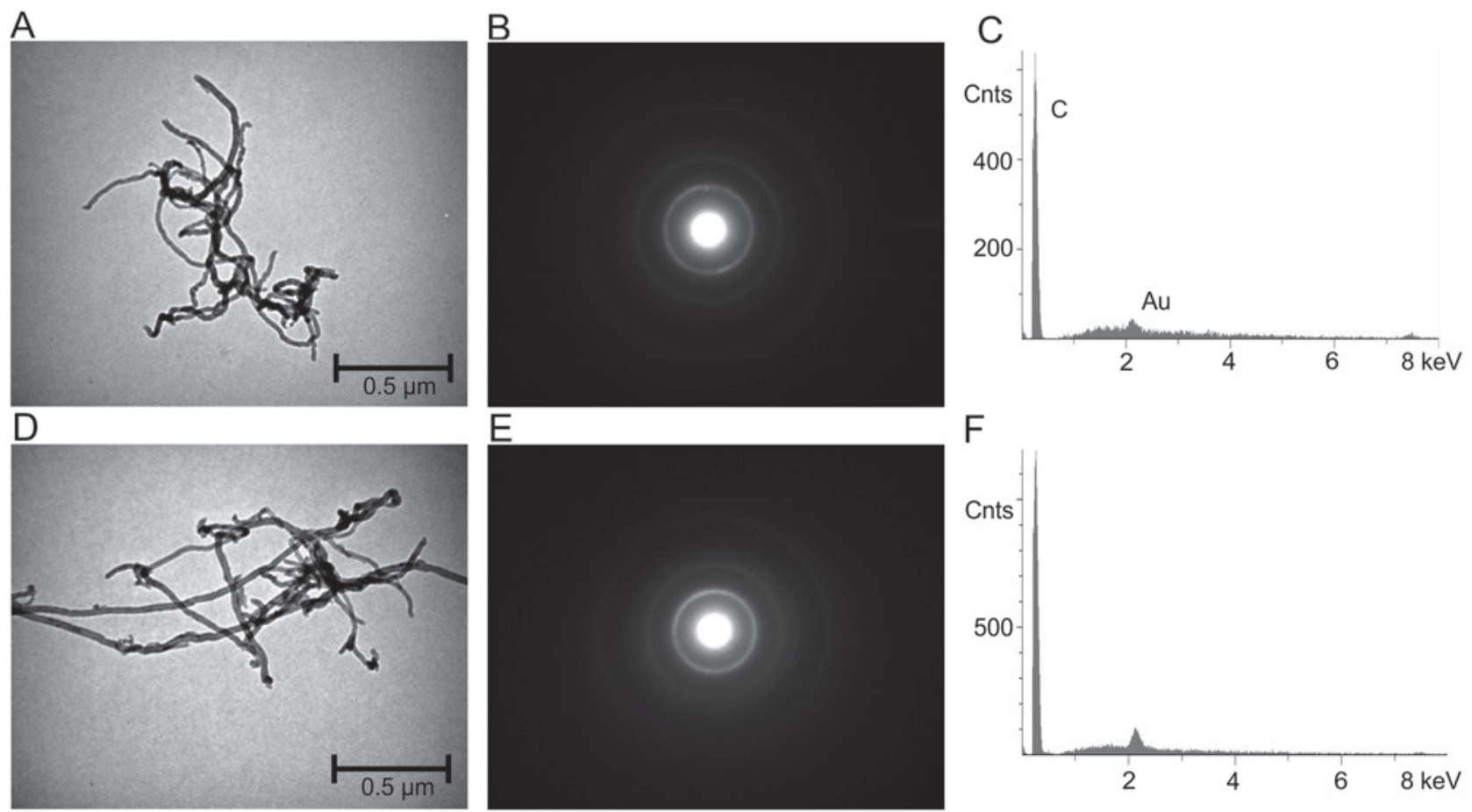

Figure 2. Transmission electron microscopy analysis of MWCN. (A) Image of MWCN 1-2 $\mu$ m (magnification, x40,000). (B) Diffraction pattern of MWCN 1-2 $\mu \mathrm{m}$. (C) Results of EDX analysis for MWCN 1-2 $\mu \mathrm{m}$. (D) Image of MWCN 5-15 $\mu \mathrm{m}$ (magnification, x40,000). (E) Diffraction pattern of MWCN 5-15 $\mu \mathrm{m}$. (F) Results of EDX analysis for MWCN 5-15 $\mu \mathrm{m}$. MWCN, multi-walled carbon nanotubes; EDX, energy dispersive X-ray.

of two dosages of the selected fibrous dusts on glycolysis, glutaminolysis and serine metabolism in cell culture: A low concentration with little or no impact on the cell proliferation rate of A549 cells, and a high concentration with a more severe impact on cell proliferation. The dosages were not selected to define the no-observed-adverse-effect-level or the lowest-observed-adverse-effect-level of the corresponding fibers. For all fibers tested, the low dosage was $1 \mu \mathrm{g} / \mathrm{cm}^{2}$ with an incubation time of $24 \mathrm{~h}$ (Fig. 4A). The high concentration was $25 \mu \mathrm{g} / \mathrm{cm}^{2}$ for glass fibers, MWCN 5-15 $\mu \mathrm{m}$ and MWCN 1-2 $\mu \mathrm{m}$ (Fig. 4B). Concentrations $>25 \mu \mathrm{g} / \mathrm{cm}^{2}$ led to an impenetrable dust carpet over the cell monolayer and were therefore not used in the present study. Chrysotile and crocidolite asbestos had a significantly increased inhibitory effect on cell proliferation in A549 cells compared with glass fibers or MWCN. For the two asbestos fibers, a dosage of $25 \mu \mathrm{g} / \mathrm{cm}^{2}$ for $48 \mathrm{~h}$ was cytotoxic. In order to achieve comparable inhibitory effects on the cell proliferation rate among the different fibers tested at the high dosage, chrysotile and crocidolite were applied at a concentration of $5 \mu \mathrm{g} / \mathrm{cm}^{2}$ for $48 \mathrm{~h}$. In the experiments for all dusts tested, neither the low dosage of $1 \mu \mathrm{g} / \mathrm{cm}^{2}$ nor the high dosage $\left(5 \mu \mathrm{g} / \mathrm{cm}^{2}\right.$ and $25 \mu \mathrm{g} / \mathrm{cm}^{2}$, respectively) had an impact on cell viability, which corresponded to a number of other studies published in the literature (33-35). At the low dosage $\left(1 \mu \mathrm{g} / \mathrm{cm}^{2}\right.$ for $\left.24 \mathrm{~h}\right)$ only chrysotile and glass fibers led to a significant inhibition (12\%) of cell proliferation compared with mock-treated controls (Fig. 4A). In the case of chrysotile, the inhibition of cell proliferation rose to $54 \%$ at the high concentration $\left(5 \mu \mathrm{g} / \mathrm{cm}^{2}\right.$ for $48 \mathrm{~h}$; Fig. 4B). Crocidolite asbestos exerted no impact at the low dosage and decreased cell proliferation by $29 \%$ at the high dosage ( $5 \mu \mathrm{g} / \mathrm{cm}^{2}$ for $\left.48 \mathrm{~h}\right)$. Similar growth inhibitory effects of chrysotile and crocidolite have been described in bronchial epithelial BEAS 2B cells (36) and human embryonic lung HEL-299 cells (37). The growth inhibitory effect of glass fibers increased from $12 \%$ inhibition at the low dosage to $22 \%$ inhibition at the high dosage $\left(5 \mu \mathrm{g} / \mathrm{cm}^{2}\right.$ for $\left.48 \mathrm{~h}\right)$. MWCN at 1-2- and 5-15- $\mu \mathrm{m}$ lengths induced a significant increase in cell proliferation (MWCN 1-2 $\mu \mathrm{m}, 16 \%$ and MWCN 5-15 $\mu \mathrm{m}, 9 \%)$ at the low dosage $\left(1 \mu \mathrm{g} / \mathrm{cm}^{2}\right.$ for $\left.24 \mathrm{~h}\right)$. At the high dosage $\left(25 \mu \mathrm{g} / \mathrm{cm}^{2}\right.$ for $\left.48 \mathrm{~h}\right)$ only the $5-15 \mu \mathrm{m}$ MWCN led to an inhibition of cell proliferation of 23\%, whereas the shorter 1-2 $\mu \mathrm{m}$ MWCN had no impact on cell proliferation compared with the mock-treated control cells. By quantifying the DNA content, Tabet et al (38) estimated a reduction in the cell number of $15-20 \%$ when A549 cells were incubated for 24,48 and $72 \mathrm{~h}$ with $20 \mu \mathrm{g} / \mathrm{cm}^{2}$ MWCN at a length of $100 \mu \mathrm{m}$ (Graphistrength C10; ARKEMA, Colombes, France); whereas, under the same conditions in mesothelial MeT5A cells, no significant effect of MWCN was observed. In the same study, $48 \mathrm{~h}$ incubation with $20 \mu \mathrm{g} / \mathrm{cm}^{2}$ crocidolite significantly increased the DNA content in A549 cells, whereas an MTT assay indicated a significant downregulation of cell viability.

Impact of chrysotile, crocidolite, glass fibers, MWCN 5-15 $\mathrm{mm}$ and MWCN 1-2 $4 \mathrm{~m}$ on glycolysis, glutaminolysis and serine metabolism. The impact of the fibrous dusts on glycolysis, glutaminolysis and serine metabolism was investigated by direct measurement of the conversion rates of glucose, pyruvate, lactate, glutamine, glutamate and serine in the culture supernatants of mock-treated and fibrous dust-treated A549 cells. In differentiated tissues, in the presence of oxygen, glucose is completely degraded to $\mathrm{CO}_{2}$ and water via cytosolic 
A
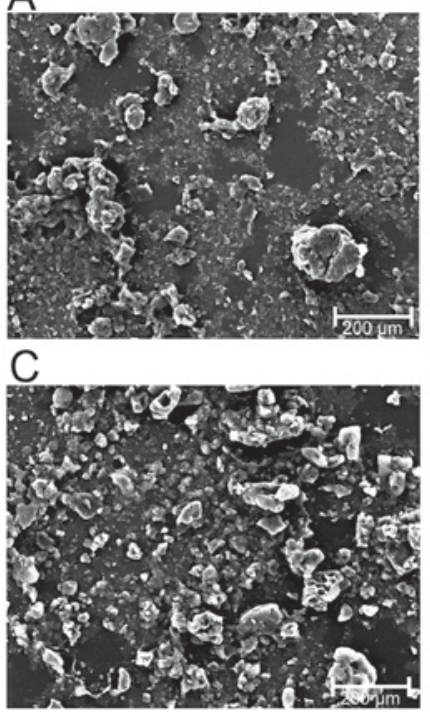

B

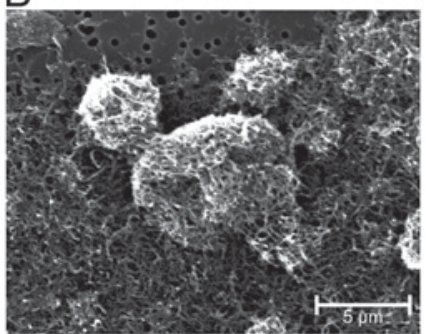

$\mathrm{D}$

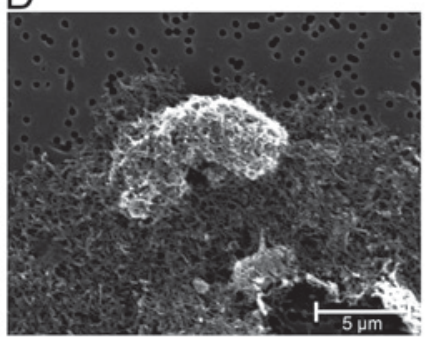

Figure 3. Scanning electron microscopy analysis of MWCN 1-2 $\mu \mathrm{m}$ at (A) magnification, $\mathrm{x} 100$ and (B) magnification, $\mathrm{x} 5,000$, and MWCN 5-15 $\mu \mathrm{m}$ at (C) magnification $x 100$ and (D) magnification, $x 5,000$ in the $10-\mu 1$ fiber suspensions used for the cell experiments on a nucleopore filter. MWCN, multi-walled carbon nanotubes.

glycolysis, the mitochondrial citric acid cycle and endoxidation in order to regenerate energy (Fig. 1). In low oxygen conditions, pyruvate is reduced to lactate within the cytosol. By contrast, in proliferating cells, including A549 cells, glycolytic pyruvate is released as lactate even in the presence of oxygen (Fig. 1). In addition to energy regeneration in proliferating cells, glycolytic intermediates serve as precursors for the synthesis of important cellular building blocks, including nucleic acids, amino acids and phospholipids, which are essential for cells with a high proliferation rate (Fig. 1) (29,30). For energy regeneration, proliferating cells utilize a novel efficient source of energy, which is the degradation of the amino acid glutamine $(27,29,39)$. Thereby extracellular glutamine is desaminated to glutamate within the mitochondria. A certain amount of the glutamate is directly released from the cells and may be identified as glutamate production in the culture supernatants of the cells (Fig. 1). A further quantity of the glutamate is converted to $\alpha$-ketoglutarate and is infiltrated into the citric acid cycle for energy regeneration. In addition, glutamate provides the amino group for serine synthesis from glycerate 3-phosphate $(\mathrm{P})$ and is a component of glutathione, an important metabolite for the detoxification of reactive oxygen species (ROS). A certain amount of the malate within the citric acid cycle is decarboxylated to pyruvate and released as lactate; thus, glutaminolysis summarizes the degradation of the amino acid glutamine to malate, $\mathrm{CO}_{2}$, pyruvate, lactate and citric acid. Additionally, glutamine is a precursor of purine and pyrimidine synthesis (Fig. 1). Pyruvate is either consumed by the cells when the metabolite is added into the medium, or is released from the cells in the absence of extracellular pyruvate. Serine is a precursor for phospholipid, glycine and cysteine synthesis and donates one-carbon units to folate, all of which are necessary for cellular building block synthesis (40). When the rate of serine synthesis exceeds the amount of serine necessary for the synthesis of cellular components, serine is
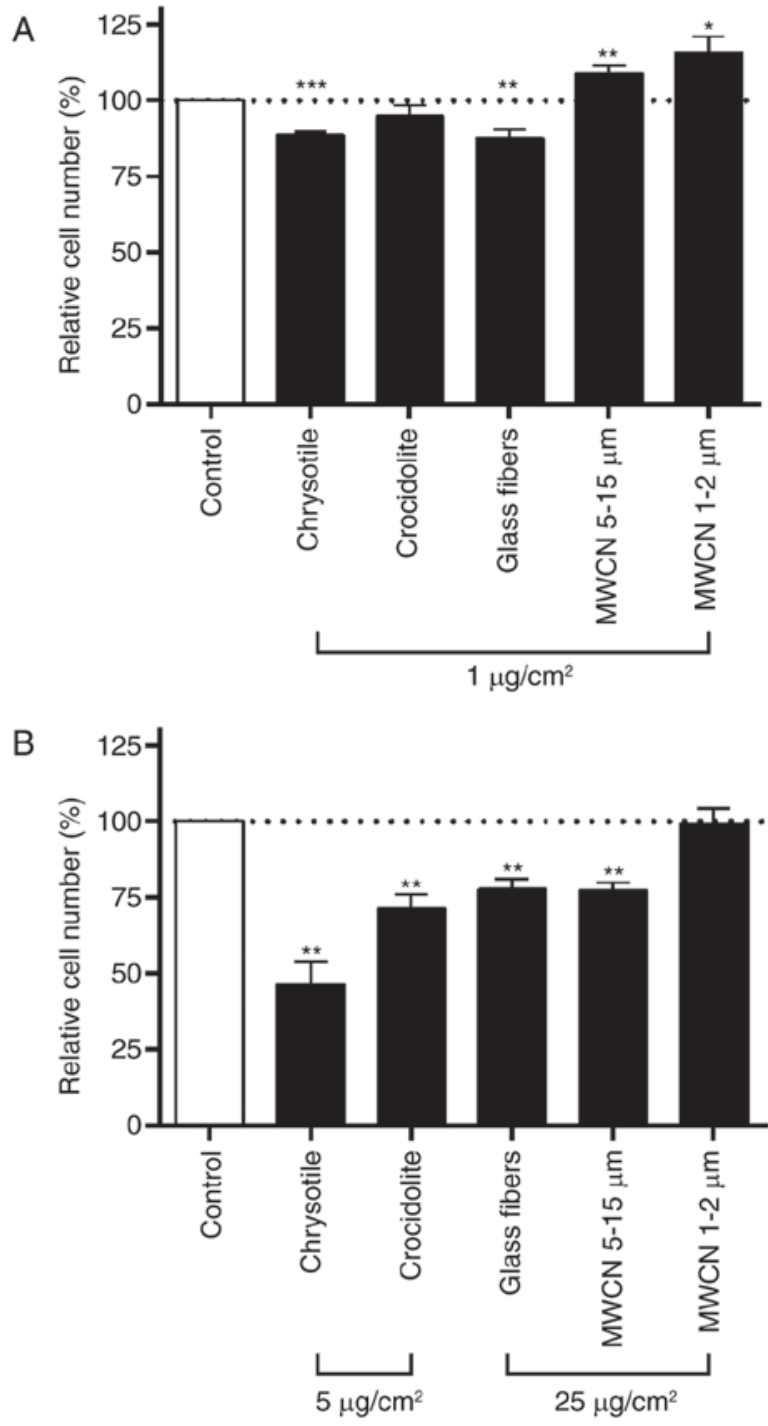

Figure 4. Effect of fibrous dusts on cell proliferation of A549 cells. (A) Dust concentration, $1 \mu \mathrm{g} / \mathrm{cm}^{2}$; incubation time, $24 \mathrm{~h}$; control, $\mathrm{n}=14$; dust-treated cells, $\mathrm{n}=6$. (B) Concentration of chrysotile and crocidolite, $5 \mu \mathrm{g} / \mathrm{cm}^{2}$; all other dusts, $25 \mu \mathrm{g} / \mathrm{cm}^{2}$; incubation time, $48 \mathrm{~h}$; control, $\mathrm{n}=6$; dust-treated cells, $\mathrm{n}=4$. The mean cell number/well of mock-treated controls was set at $100 \%$. Data are presented as the mean \pm standard error of the mean. ${ }^{*} \mathrm{P}<0.05 ;{ }^{* *} \mathrm{P}<0.01$; **** $\mathrm{P}<0.001$ vs. control.

released from the cells. However, when the cells are unable to synthesize serine in sufficient amounts, serine is consumed from the medium $(40,41)$.

At the low dosage tested in the present study $\left(1 \mu \mathrm{g} / \mathrm{cm}^{2}\right.$ dust for $24 \mathrm{~h}$ ) none of the fibrous dusts tested led to a significant alteration in the conversion rates of glucose, lactate, pyruvate, glutamine, glutamate and serine (Fig. 5). At high dosages, the most marked effect on the metabolic conversion rates was observed with chrysotile (Fig. 5 A-E). Glucose and glutamine consumption, in addition to pyruvate, lactate and glutamate production, significantly increased within $48 \mathrm{~h}$ incubation of A549 cells with $5 \mu \mathrm{g}$ chrysotile $/ \mathrm{cm}^{2}$. The other fibrous dusts did also increase the conversion rates of these metabolites. However, the extent of the effects decreased in the following order: Chrysotile $\left(5 \mu \mathrm{g} / \mathrm{cm}^{2}\right)>$ crocidolite $\left(5 \mu \mathrm{g} / \mathrm{cm}^{2}\right)>$ glass fibers $\left(25 \mu \mathrm{g} / \mathrm{cm}^{2}\right)>$ MWCN $5-15 \mu \mathrm{m}\left(25 \mu \mathrm{g} / \mathrm{cm}^{2}\right)>$ MWCN $1-2 \mu \mathrm{m}\left(25 \mu \mathrm{g} / \mathrm{cm}^{2}\right)$. 

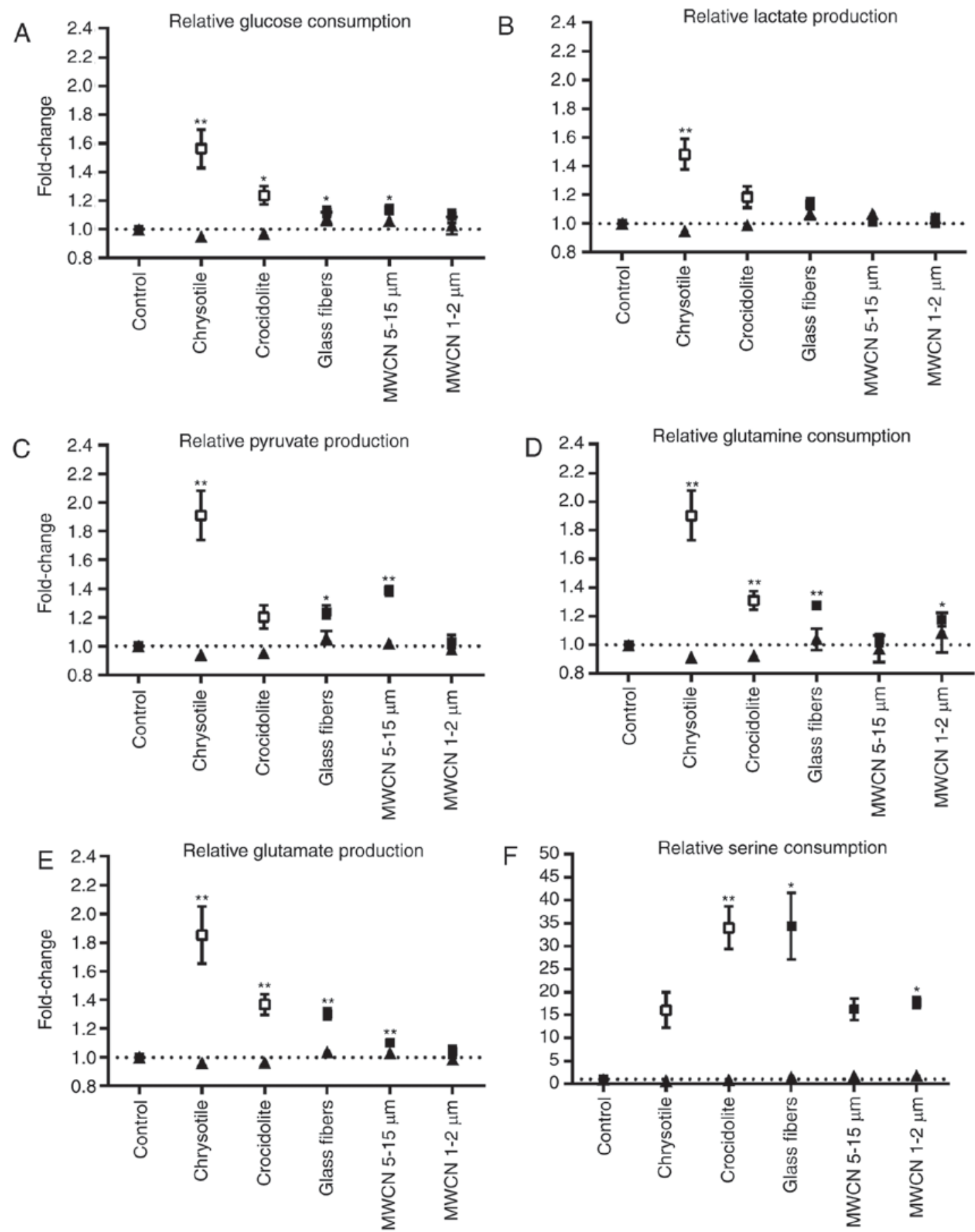

Figure 5. Relative metabolic conversion rates in dust-treated A549 cells compared with mock-treated controls. The mean value of mock-treated controls was set at 1 and (A) glucose consumption rates, (B) lactate production rates, (C) pyruvate production rates, (D) glutamine consumption rates, (E) glutamate production rates and $(F)$ serine consumption rates of dust-treated cells were calculated compared with the control value. Data are presented as the mean \pm standard error of the mean. $\mathbf{\Lambda}$, dust concentration $=1 \mu \mathrm{g} / \mathrm{cm}^{2} ;$ control, $\mathrm{n}=14$; all dust-treated cells, $\mathrm{n}=6$. $\square$, concentration of chrysotile and crocidolite $=5 \mu \mathrm{g} / \mathrm{cm}^{2} ; \mathbf{m}$, concentration of all other dusts $=25 \mu \mathrm{g} / \mathrm{cm}^{2}$; control $\mathrm{n}=6$; all dust-treated cells, $\mathrm{n}=4 .{ }^{*} \mathrm{P}<0.05 ;{ }^{* * *} \mathrm{P}<0.01$ vs. control.

At first glance the increase in glucose and glutamine consumption observed for the fibrous dusts tested in the present study points to an increase in the metabolic activity within the cells. However, the simultaneous increase in pyruvate, lactate and glutamate release indicates that the amount of glucose and glutamine channeled into the debranching synthetic processes for cellular components was decreased in the presence of fibrous dusts at non-toxic concentrations. This assumption is additionally supported by the increase in serine uptake observed for certain of the fibrous dusts tested (Fig. 5F). The amino acid serine is synthesized from the glycolytic intermediate glycerate 3-P and the glutaminolytic intermediate glutamate (Fig. 1). Serine metabolism is regulated, inter alia, by the transcription factors cellular tumor antigen p53 (p53) and Myc proto-oncogene protein (Myc) (40). p53 suppresses the expression of phosphoglycerate dehydrogenase (PHGDH), the first enzyme in serine synthesis. Myc has been demonstrated to enhance the expression of 
PHGDH, in addition to phosphoserine aminotransferase 1 and phosphoserine phosphatase, the two following enzymes within serine synthesis. Concurrently with hypoxia-inducible factor $1-\alpha(\mathrm{HIF} 1 \alpha)$, Myc activates the expression of serine hydroxymethyltransferase 2 , which catalyzes the reversible reaction of serine and tetrahydrofolate to glycine and 5,10-methylene tetrahydrofolate. According to results published by Matsuoka et al (22), treatment with chrysotile and crocidolite led to a dose- and time-dependent increase in Ser15 phosphorylation and the stabilization of p53 in A549 cells. A p53-regulated downregulation of serine synthesis may be an explanation for the increased serine uptake observed in the chrysotile- and crocidolite-treated A549 cells in the present study (Fig. 5F). A crocidolite-associated stabilization of p53 in A549 cells was additionally described by Johnson and Jaramillo (23). In the same study, JM 100 glass microfiber did not induce an increase in p53 (23); whereas, in the present study, in glass fiber-treated A549 cells the increase in serine uptake was among the highest compared with the other fibers tested. In addition, continuous exposure of primary human lung small airway epithelial cells immortalized with human telomerase reverse transcriptase for 6 months to $0.02 \mu \mathrm{g} / \mathrm{cm}^{2}$ dispersed carbon nanotubes (single-walled and MWCN) and crocidolite induced an overexpression of cMyc, while p53 was underexpressed (42). In addition to numerous other cellular targets, Myc is an important transcriptional upregulator of glycolytic enzymes and glutaminolytic glutaminase (43), which may serve a regulatory role in the fiber-dependent increase in glucose and glutamine consumption observed in the present study. However, the increase in glutamate production in the present study was an indication that a high amount of glutamine consumed in the fibrous dust-treated cells was not converted in glutaminolysis (Fig. 5D and E). Further investigations into the level of gene expression regulation are required to clarify the underlying mechanism of the fiber-dependent increase in glucose, glutamine and serine uptake observed in A549 cells in the present study.

The increase in glucose, glutamine and serine consumption observed in the fibrous dust-treated A549 cells may be interpreted as a metabolic mechanism to compensate for the inhibition of cellular building block synthesis. However, the inhibition of cell proliferation suggests an interruption of the metabolic regulation between the provision of cellular components and energy regeneration. Few studies have addressed the effect of fibrous dusts on the metabolism of cells. In accordance with the results of the present study, Riganti et al (44) described a dose-dependent inhibition of the oxidative pentose-P pathway in A549 cells due to the direct interaction of crocidolite with glucose 6-P dehydrogenase (G6PDH). The oxidative pentose-P pathway provides ribose 5-P for nucleic acid synthesis in addition to reduced nicotinamide adenine dinucleotide phosphate (NADPH) $+\mathrm{H}^{+}$for glutathione recycling, for example (Fig. 1). G6PDH is responsible for $\mathrm{NADPH}+\mathrm{H}^{+}$regeneration, which is necessary for the recycling of glutathione, the principal antioxidant cellular pathway (Fig. 1). An inhibition of G6PDH and glutathione recycling is a conceivable explanation for the increase in ROS production described in asbestos- $(37,45,46), \mathrm{MWCN}-(46)$ and glass fiber- (45) treated cells. In the present study, the cells were incubated with $5 \mu \mathrm{g}$ crocidolite $/ \mathrm{cm}^{2}$ for $48 \mathrm{~h}$. Notably, in the study of Golladay et al (47), 24 h incubation of A549 cells with $3 \mu \mathrm{g} / \mathrm{cm}^{2}$ crocidolite led to a release of $75 \%$ of the intracellular glutathione into the medium, which was not induced by nonspecific membrane damage. High ROS concentrations have been demonstrated to stabilize the alpha subunit of HIF1 (48), which is an important transcriptional upregulator of glycolytic enzymes. ROS-induced HIF1 $\alpha$ stabilization and HIF1-induced upregulation of important glycolytic enzymes may be an explanation for the observed increase in glycolytic conversion rates in the dust-treated A549 cells (Fig. 5A-C). Notably, in pulmonary alveolar macrophages treated with $25 \mu \mathrm{g} / \mathrm{cm}^{2}$ chrysotile fibers for $18 \mathrm{~h}$, a decrease in ATP levels of $20-30 \%$ has been described (49) which indicates that, in addition to the synthesis of cellular building blocks, energy regeneration is impaired by treatment with chrysotile.

Classification of observed effects. For the concentrations tested in the present study, and with respect to the inhibitory effect on cell proliferation (Fig. 4) as well as the extent of the metabolic alterations (Fig. 5), the results revealed the following ranking among the fibers tested: Chrysotile $>$ crocidolite $>$ glass fibers $>$ MWCN 5-15 $\mu \mathrm{m}>$ MWCN 1-2 $\mu \mathrm{m}$. For the asbestos fibers and MMVF this ranking correlated best with the number of fibers (chrysotile, 800 million fibers $/ \mathrm{mg}>$ crocidolite, 130 million fibers $/ \mathrm{mg}>$ glass fibers, 0.26 million fibers $/ \mathrm{mg}$ ). In these fibers, the effects on cell proliferation and cellular metabolism decreased with a decreasing number of fibers. It appeared that the results observed for MWCN 5-15 $\mu \mathrm{m}$ and MWCN 1-2 $\mu \mathrm{m}$ were not consistent with this trend. Nano-sized fibers $(\mathrm{MWCN})$ are characterized by greater numbers of fibers per unit of mass compared with chrysotile, crocidolite and glass fibers. However, the effects of MWCN 5-15 $\mu \mathrm{m}$ and 1-2 $\mu \mathrm{m}$ on cell proliferation and cellular metabolism were the lowest in the present study (Figs. 4 and 5). Therefore, the behavior of the MWCN in fluids was examined using SEM, which demonstrated the strong tendency to form agglomerates of MWCN 5-15 $\mu \mathrm{m}$ and MWCN 1-2 $\mu \mathrm{m}$ (Fig. 3). Compared with the longer MWCN 5-15 $\mu \mathrm{m}, \mathrm{MWCN} 1-2 \mu \mathrm{m}$ agglomerate to larger units. Consequently, the functionally-relevant number of fibers is markedly decreased by agglomeration. This explains why the observed effects of MWCN on cell proliferation and metabolism were the lowest by mass in the ranking produced in the present study.

In conclusion, the determination of glycolytic, glutaminolytic and serine conversion rates in the culture supernatants of cell cultures is a rapid and effective method of obtaining an impression of the impact of chemicals on the metabolic signature and physiological status of cells. For the fibrous dusts tested in the present study, the metabolic signature in A549 cells revealed a ranking which correlated best with the relevant number of fibers. Based on these results, in future experiments, a comparable concentration-dependent analysis of the intracellular concentrations of the transcription factors HIF1, c-Myc and p53, the protein content and enzymatic activity of important enzymes in glycolysis, glutaminolysis and serine metabolism, the metabolic intermediates of the corresponding pathways and the energy charge may help to localize the molecular targets of the fibrous dusts tested and to explain the underlying molecular mechanism of the ranking between the different dusts disclosed in the present study (50). 


\section{References}

1. Thermal Insulation Manufactures Association, Nomenclature Committee: Manmade vitreous fibers. Nomenclature, chemistry and physical properties. The Committe, Stanford, CT, 1991

2. IARC Working Group on the Evaluation of Carcinogenic Risks to Humans: Man-made vitreous fibres. IARC Monogr Eval Carcinog Risks Hum 81: 1-381, 2002.

3. IARC Working Group on the Evaluation of Carcinogenic Risks to Humans: Arsenic, metals, fibres, and dusts. IARC Monogr Eval Carcinog Risks Hum 100: 11-465, 2012.

4. World Health Organization: Determination of airborne fibre number concentrations. A recommended method, by phase-contrast optical microscopy, membrane filter method. World Health Organization, Geneva, 1997.

5. Schinwald A, Chernova T and Donaldson $\mathrm{K}$ : Use of silver nanowires to determine thresholds for fibre length-dependent pulmonary inflammation and inhibition of macrophage migration in vitro. Part Fibre Toxicol 9: 47, 2012.

6. Schinwald A and Donaldson K: Use of back-scatter electron signals to visualise cell/nanowires interactions in vitro and in vivo; frustrated phagocytosis of long fibres in macrophages and compartmentalisation in mesothelial cells in vivo. Part Fibre Toxicol 9: 34, 2012

7. Rittinghausen S, Hackbarth A, Creutzenberg O, Ernst H, Heinrich U, Leonhardt A and Schaudien D: The carcinogenic effect of various multi-walled carbon nanotubes (MWCNTs) after intraperitoneal injection in rats. Part Fibre Toxicol 11: 59, 2014.

8. Poland CA, Duffin R, Kinloch I, Maynard A, Wallace WA, Seaton A, Stone V, Brown S, Macnee W and Donaldson K: Carbon nanotubes introduced into the abdominal cavity of mice show asbestos-like pathogenicity in a pilot study. Nat Nanotechnol 3: 423-428, 2008.

9. van Berlo D, Wilhelmi V, Boots AW, Hullmann M, Kuhlbusch TA, Bast A, Schins RP and Albrecht C: Apoptotic, inflammatory, and fibrogenic effects of two different types of multi-walled carbon nanotubes in mouse lung. Arch Toxicol 88: 1725-1737, 2014.

10. DFG: Fibrous Dust [MAK Value Documentation]. Wiley-VCH Verlag GmbH \& Co. KGaA, Weinheim, pp142-338, 1997.

11. Nymark P, Lindholm PM, Korpela MV, Lahti L, Ruosaari S, Kaski S, Hollmén J, Anttila S, Kinnula VL and Knuutila S: Gene expression profiles in asbestos-exposed epithelial and mesothelial lung cell lines. BMC Genomics 8: 62, 2007.

12. Hevel JM, Olson-Buelow LC, Ganesan B, Stevens JR, Hardman JP and Aust AE: Novel functional view of the crocidolite asbestos-treated A549 human lung epithelial transcriptome reveals an intricate network of pathways with opposing functions. BMC Genomics 9: 376, 2008.

13. Helmig S, Dopp E, Wenzel S, Walter D and Schneider J: Induction of altered mRNA expression profiles caused by fibrous and granular dust. Mol Med Rep 9: 217-228, 2014.

14. Armand L, Biola-Clier M, Bobyk L, Collin-Faure V, Diemer H, Strub JM, Cianferani S, Van Dorsselaer A, Herlin-Boime N, Rabilloud T and Carriere M: Molecular responses of alveolar epithelial A549 cells to chronic exposure to titanium dioxide nanoparticles: A proteomic view. J Proteomics 134: 163-173, 2016.

15. Lieber M, Smith B, Szakal A, Nelson-Rees W and Todaro G: A continuous tumor-cell line from a human lung carcinoma with properties of type II alveolar epithelial cells. Int J Cancer 17: 62-70, 1976.

16. Witherden IR, Vanden Bon EJ, Goldstraw P, Ratcliffe C, Pastorino U and Tetley TD: Primary human alveolar type II epithelial cell chemokine release: Effects of cigarette smoke and neutrophil elastase. Am J Respir Cell Mol Biol 30: 500-509, 2004.

17. Foster KA, Oster CG, Mayer MM, Avery ML and Audus KL: Characterization of the A549 cell line as a type II pulmonary epithelial cell model for drug metabolism. Exp Cell Res 243: 359-366, 1998

18. Giard DJ, Aaronson SA, Todaro GJ, Arnstein P, Kersey JH, Dosik $\mathrm{H}$ and Parks WP: In vitro cultivation of human tumors: Establishment of cell lines derived from a series of solid tumors. J Natl Cancer Inst 51: 1417-1423, 1973.

19. Wottrich R, Diabaté S and Krug HF: Biological effects of ultrafine model particles in human macrophages and epithelial cells in monoand co-culture. Int J Hyg Environ Health 207: 353-361, 2004.

20. Castell JV, Donato MT and Gómez-Lechón MJ: Metabolism and bioactivation of toxicants in the lung. The in vitro cellular approach. Exp Toxicol Pathol 57 (Suppl 1): S189-S204, 2005.
21. Nagatomo H, Morimoto Y, Ogami A, Hirohashi M, Oyabu T, Kuroda K, Higashi T and Tanaka I: Change of heme oxygenase-1 expression in lung injury induced by chrysotile asbestos in vivo and in vitro. Inhal Toxicol 19: 317-323, 2007.

22. Matsuoka M, Igisu H and Morimoto Y: Phosphorylation of p53 protein in A549 human pulmonary epithelial cells exposed to asbestos fibers. Environ Health Perspect 111: 509-512, 2003.

23. Johnson NF and Jaramillo RJ: p53, Cip1, and Gadd153 expression following treatment of A549 cells with natural and man-made vitreous fibers. Environ Health Perspect 105 (Suppl 5): S1143-S1145, 1997.

24. Signorelli S, Jennings P, Leonard MO and Pfaller W: Differential effects of hypoxic stress in alveolar epithelial cells and microvascular endothelial cells. Cell Physiol Biochem 25: 135-144, 2010.

25. Jing XG, Chen TF, Huang C, Wang H, An L, Cheng Z and Zhang GJ: MiR-15a expression analysis in non-small cell lung cancer A549 cells under local hypoxia microenvironment. Eur Rev Med Pharmacol Sci 21: 2069-2074, 2017.

26. ATCC®.org.: 'A549 cell line: CCl-185 product description, documentation p53 hotspot mutation data'. https://www. lgcstandards-atcc.org/ /media/2B3C84F951E24E668C78EB70 809C7613.ashx.

27. DeBerardinis RJ, Mancuso A, Daikhin E, Nissim I, Yudkoff M, Wehrli $\mathrm{S}$ and Thompson CB: Beyond aerobic glycolysis: Transformed cells can engage in glutamine metabolism that exceeds the requirement for protein and nucleotide synthesis. Proc Natl Acad Sci USA 104: 19345-19350, 2007.

28. Eigenbrodt E, Kallinowski F, Ott M, Mazurek S and Vaupel P: Pyruvate kinase and the interaction of amino acid and carbohydrate metabolism in solid tumors. Anticancer Res 18: 3267-3274, 1998.

29. Mazurek S, Boschek CB, Hugo F and Eigenbrodt E: Pyruvate kinase type M2 and its role in tumor growth and spreading. Semin Cancer Biol 15: 300-308, 2005.

30. Christofk HR, Vander Heiden MG, Harris MH, Ramanathan A, Gerszten RE, Wei R, Fleming MD, Schreiber SL and Cantley LC: The M2 splice isoform of pyruvate kinase is important for cancer metabolism and tumour growth. Nature 452: 230-233, 2008.

31. Mazurek S, Michel A and Eigenbrodt E: Effect of extracellular AMP on cell proliferation and metabolism of breast cancer cell lines with high and low glycolytic rates. J Biol Chem 272: 4941-4952, 1997

32. Unterluggauer H, Mazurek S, Lener B, Hütter E, Eigenbrodt E, Zwerschke W and Jansen-Dürr P: Premature senescence of human endothelial cells induced by inhibition of glutaminase. Biogerontology 9: 247-259, 2008.

33. Li P, Liu T, Kamp DW, Lin Z, Wang Y, Li D, Yang L, He H and Liu G: The c-Jun N-terminal kinase signaling pathway mediates chrysotile asbestos-induced alveolar epithelial cell apoptosis. Mol Med Rep 11: 3626-3634, 2015.

34. Leyva FJ and Roberts K: Crocidolite induces prostaglandin I(2) release mediated by vitronectin receptor and cyclooxygenase-2 in lung cells. Lung 188: 133-141, 2010.

35. Srivastava RK, Lohani $M$, Pant AB and Rahman Q: Cyto-genotoxicity of amphibole asbestos fibers in cultured human lung epithelial cell line: Role of surface iron. Toxicol Ind Health 26: 575-582, 2010.

36. Nymark P, Jensen KA, Suhonen S, Kembouche Y, Vippola M, Kleinjans J, Catalán J, Norppa H, van Delft J and Briedé JJ: Free radical scavenging and formation by multi-walled carbon nanotubes in cell free conditions and in human bronchial epithelial cells. Part Fibre Toxicol 11: 4, 2014.

37. Ueki A: Biological effects of asbestos fibers on human cells in vitro-especially on lymphocytes and neutrophils. Ind Health 39: 84-93, 2001.

38. Tabet L, Bussy C, Amara N, Setyan A, Grodet A, Rossi MJ, Pairon JC, Boczkowski J and Lanone S: Adverse effects of industrial multiwalled carbon nanotubes on human pulmonary cells. J Toxicol Environ Health A 72: 60-73, 2009.

39. Lobo C, Ruiz-Bellido MA, Aledo JC, Márquez J, Núnez de Castro I and Alonso FJ: Inhibition of glutaminase expression by antisense mRNA decreases growth and tumourigenicity of tumour cells. Biochem J 348: 257-261, 2000.

40. Yang $\mathrm{M}$ and Vousden KH: Serine and one-carbon metabolism in cancer. Nat Rev Cancer 16: 650-662, 2016.

41. Mazurek S, Zwerschke W, Jansen-Dürr P and Eigenbrodt E: Effects of the human papilloma virus HPV-16 E7 oncoprotein on glycolysis and glutaminolysis: Role of pyruvate kinase type M2 and the glycolytic-enzyme complex. Biochem J 356: 247-256, 2001. 
42. Wang L, Stueckle TA, Mishra A, Derk R, Meighan T, Castranova V and Rojanasakul Y: Neoplastic-like transformation effect of single-walled and multi-walled carbon nanotubes compared to asbestos on human lung small airway epithelial cells. Nanotoxicology 8: 485-507, 2014. doi: 10.3109/17435390.2013.801089.

43. Dang CV: Rethinking the Warburg effect with Myc micromanaging glutamine metabolism. Cancer Res 70: 859-862, 2010.

44. Riganti C, Aldieri E, Bergandi L, Fenoglio I, Costamagna C, Fubini B, Bosia A and Ghigo D: Crocidolite asbestos inhibits pentose phosphate oxidative pathway and glucose 6-phosphate dehydrogenase activity in human lung epithelial cells. Free Radic Biol Med 32: 938-949, 2002.

45. Cardinali G, Kovacs D, Maresca V, Flori E, Dell'Anna ML, Campopiano A, Casciardi S, Spagnoli G, Torrisi MR and Picardo M: Differential in vitro cellular response induced by exposure to synthetic vitreous fibers (SVFs) and asbestos crocidolite fibers. Exp Mol Pathol 81: 31-41, 2006.
46. Garza KM, Soto KF and Murr LE: Cytotoxicity and reactive oxygen species generation from aggregated carbon and carbonaceous nanoparticulate materials. Int J Nanomedicine 3: 83-94, 2008.

47. Golladay SA, Park SH and Aust AE: Efflux of reduced glutathione after exposure of human lung epithelial cells to crocidolite asbestos. Environ Health Perspect 105 (Suppl 5): S1273-S1277, 1997.

48. Finkel T: Signal transduction by mitochondrial oxidants. J Biol Chem 287: 4434-4440, 2012.

49. Nadeau D and Lane DA: The cytotoxicity of chrysotile asbestos fibers to pulmonary alveolar macrophages. I. Effects of inhibitors of ADP-ribosyl transferase. Cell Biol Toxicol 4: 13-30, 1988.

50. Pink M, Verma N, Rettenmeier AW and Schmitz-Spanke S: Integrated proteomic and metabolomic analysis to assess the effects of pure and benzo[a]pyrene-loaded carbon black particles on energy metabolism and motility in the human endothelial cell line EA.hy926. Arch Toxicol 88: 913-934, 2014. 